\title{
INVASION JITTERS, NAPOLEONIC PERIOD
}

\author{
BY ROBERT A. AUBIN
}

THE large collection of bound pamphlets among which Professor A ubin found the seven tracts which he here describes were brought together by William Campbell, President of Rutgers College from ${ }_{1} 862$ to 1882 . To those who delve into the remoter corners of the Library, these volumes constitute a mysterious mine of possible treasures. Dr. Aubin, of the Department of English of the New Jersey College for Women, is one of our old contributors.

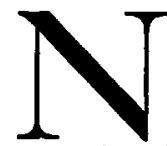

EWSPAPERS in the early i 800's were fewer and less influential than they are today, for the stamp-tax made them dear, and slow communication restricted circulation; accordingly, other vehicles of popular education such as broadsides, caricatures, songs, sermons, and pamphlets flourished. The Library possesses a typographical deluge of early nineteenth-century pamphlets, which about a century ago were assembled into a host of fragile and forbidding volumes. In ploughing up this dust-heap of propaganda on causes long since forgotten, I happened upon seven tracts, published in $\mathrm{r} 803$ and $\mathrm{I} 804$, to which recent events had given a fortuitous interest, for in them Britain is revealed alone and unprepared, facing the France of Napoleon, a nation with more than twice her population, which dominated the Continent and was infused with a strange fanaticism.

These tracts reflect conditions that arose from the humiliating Peace of Amiens (March I 802-May I 803). It is true that even before this lull England had anticipated invasion. The abortive landings in Ireland and Wales in, respectively, I 796 and I 797 had quite justified Coleridge in his "Fears in Solitude." Indeed, if Napoleon had not abruptly abandoned his designs on Britain in favor of his Egyptian adventure (and only four days before the Irish rebelled), I 798 might be remembered today for something even more important than Lyrical Ballads. Then too, in I $80 \mathrm{o}$ Bonaparte, now First Consul and recent victor at Marengo, had returned to Boulogne and begun to collect barges, which Nelson had twice attempted to bombard. Now came the uneasy truce of fourteen months during which England embarked upon a policy of unilateral disarmament and reduced her armed forces by 40,000 . Hence when in 1803 war was resumed, she found herself in a pretty pickle. With funds obtained 
in part from the Louisiana Purchase, Napoleon fortified the coast opposite England and constructed a number of camps including four great ones at Boulogne, the site of his headquarters. With prodigious energy (he is said to have worn out twenty-seven pairs of riding breeches) he assembled about 200,000 soldiers, whom he drilled, reviewed, and set to dredging harbors and practicing embarking and disembarking in some 2000 flat-bottomed barges. His men were trained and eager; they had posted the road from Amiens "To England." And Napoleon was serious in his intentions, for he needed to dazzle the canaille and had been irked by Parisian wits who had jeered at his delays and had dubbed him "Don Quixote de la Manche"; above all, he hated the British, who stood between him and world conquest. For the moment he waged a war of nerves by parading his intentions and his might. He sent the Bayeux tapestry on tour, turned the "iron coast" into a fortress, had medals struck dated from London in I 804, assembled I I 7 Guide-Interpreters to accompany his army of invasion, and encouraged departments, towns, and individuals to vie with one another in contributing transports. He even investigated Robert Fulton's diving ship and submarine torpedo. As he stood with his spy-glass outside his headquarters, surrounded by great guns whose concussions broke his windows, he schemed to gain control of the Channel if only for six hours, enough time, he believed, to make invasion practicable.

Such was England's sudden peril after the expiration of the Peace of Amiens. For her I 803 and I 804 were most crucial years. Alone she stood, with restless Ireland at her back, scanty coastal defences dating for the most part from the reigns of Henry VIII and Charles II, a Tory government that was corrupt and inert, a restive lower class, and a ridiculously inadequate army. The great majority of the nation accepted the certainty of invasion. "That Buonaparte soon will, and must, attempt an invasion, fools only cannot foresee, and traitors only dare to deny." Print-shops were stocked with bloodcurdling posters depicting Napoleon's cruelty and enormous resources, including such secret weapons as invasion craft 700 yards long, 350 wide, and eight storeys high, air-borne troops in great balloons, a Channel tunnel, and a Gargantuan bridge to extend from Calais to Dover. The coastal areas lived in a state of alert punctuated

${ }^{1}$ Cobbett's Spirit of the Public Journals, I (July 2, 1804), 609. 
by false alarms (as we gather from Scott and Hardy). There were spy-hunts and repression of popular reform movements. Yet the royal family summered imperturbably at Weymouth, and inland dwellers like Jane Austen in Hampshire and Wordsworth in the Lake District seem to have been inconvenienced scarcely at all.

The chief sources of English confidence lay in that invaluable gift of the last Ice Age, the Channel, and in a mighty navy, which quantitatively and qualitatively was at least double the strength of that of France but which in addition to protecting the homeland had to blockade the Continent, watch the enemy fleets, guard British colonies and shipping, and prey upon French commerce. Behind this first line of defence Britain improvised her land forces. Temporarily dropping her old prejudice against a standing army but still resolute against adopting conscription, she hastily increased the numbers of her regular army and militia to I 80,000 and enrolled about 400,000 volunteers in a home guard that was better armed with good intentions than with weapons of war. Indeed, patriotism was more in evidence than logic, what with every unit of service competing for recruits with every other and insisting on sporting its own regulations and uniform (generally violently colorful). Patriotic ardor manifested itself, too, in the erection of seventy-four Martello towers ${ }^{2}$ and innumerable beacons, and in the printing of what-to-do-in-aninvasion leaflets. People in the path of the invader were directed to remove everything of value and to keep the roads clear for British troop movements. London was to be held at all costs. The royal family was to be sent to the Episcopal Palace at Worcester and the crown jewels and the gold in the Bank to Worcester Cathedral. In the excitement of the moment faction and to some extent even caste were dropped: the great Whig leader, Charles James Fox, enlisted as a private in the Chertsey Volunteers. Some of the poets assisted with their pens: Charles Dibdin composed his songs of defiance, and Wordsworth his sonnet "To the Men of Kent" and other invasion pieces. James Gillray caricatured "Little Boney." Even the "Females of Great Britain" (divided into "Ladies," "Women," and "Labour-

${ }^{2}$ The name is derived from Cape Mortella in Corsica, where the original tower with its single gun had inflicted much damage on British shipping. These Martello towers were round and about thirty feet high, with brick walls nine feet thick toward the sea and six on the landward side. Each was armed with a swivel gun and two howitzers. The garrison was expected to hold out until help arrived. 
ing Women") were instructed in ways of aiding their heroic menfolk, particularly in avoiding "all Screamings, Faintings, \&c. when our Enemies appear, as out of Time and Place."

Although our seven pamphlets afford only slight glimpses into this thunderous period, the diversity of their matter and temper is striking. Let us examine them as some future historian may a few surviving specimens of the invasion literature of World War II.

Earliest in date of composition is A Sketch of All the Invasions, or Descents, upon the British Islands, from the Landing of William the Conqueror to the Present Time. To Which Are Prefixed, Thoughts on the French Invasion of England, by General Dumourier. Translated from the French. ${ }^{4}$ The bulk of this tract (first published in 1801 ) provides accounts of forty-eight invasions of the British Isles, from that of Duke William to the fiasco at Donegal

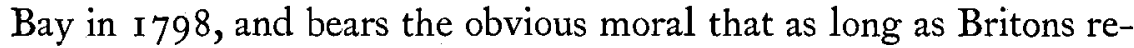
main united, they have nothing to fear. More to the point are the remarks of the Frenchman, General Charles François du Périer Dumouriez, who while Governor of Cherbourg in the I780's had prepared a plan for the invasion of England. During the early stages of the war he had led Revolutionary forces in Belgium with great distinction; thereafter he had broken with the leaders of the new French government and had fled first to Austria and eventually to England, where he had become a protagonist of the Bourbon Restoration and an advisor of the British War Office. In I 803 and I804 he drew up complete plans for the defence of the island. The earlier work of his here presented to the British public in translation affords a pretty example of the balance struck so frequently in the invasion literature between the traditional invincibility of the island and her immediate and grave danger. The English, it seems, are superior at sea only because the French have "been necessitated to sustain an universal war, which occupied all their talents, and all their population"; ${ }^{5}$ should the French concentrate on naval strength with all the

3 "Old England to Her Daughters. Address to the Females of Great Britain," in Frank J. Klingberg and S. B. Hustvedt, The Warning Drum. The British Home Front Faces Napoleon. Broadsides of 1803 (University of California Press, 1944), p. 77.

${ }^{4}$ London, 6 ed., 1803 , 4to, 46 pp. The Preface is signed "J.J.S." (J. J. Stockdale. See J. Holland Rose, Dumouriez and the Defence of England against Napoleon, London, 1909, p. 498).

${ }^{5}$ Page 4. 
Continental shipyards at their disposal, a descent upon Britain would become entirely practicable. Such an invasion might take the form either of a mass attempt at one place and time, or of a series of minor landings directed at many objectives. The latter is more likely, since experienced troops once dug in are more than a match for amateurs. The invaders, moreover, will be aided by the fog, winds, and currents of the Channel, which impede patrolling, and by the numerous discontented British who are only too eager to be liberated. The stakes are supremely high, and the French will act accordingly.

This work was printed, seemingly, to arouse serious apprehension. In contrast to it stands a vainglorious screed, the second of our pamphlets, entitled Rassurez Vous; or, The Improbability of an Invasion, and the Impossibility of Its Success Demonstrated, published, perhaps significantly, in remote Edinburgh. ${ }^{\circ}$ It aims to ridicule alarmists, first by revealing Napoleon as a liar, lucky opportunist, looting bully, cuckold, bloodthirsty coward, and second-rate intriguer.

The truth must be told: It is the name of Buonaparte, the fame of his exploits, and the opinion of the inexhaustible resources of his genius, that has distracted our avocations, circumscribed our military exertions, and terrified our women, and our women-like men. ${ }^{7}$

Next, it attempts to demonstrate that England was formerly in far greater danger of invasion than at present. With her extensive conquests to police, France is far from being strong; her true purpose in menacing us is to commit us to the permanent support of great land forces, which means economic ruin. Finally, granting that invasion is possible, it cannot succeed. If we scorch our earth in Napoleon's path, the number of ships he will require to supply his invading forces will be astronomical. Furthermore, he must have ideal weather, not for hours merely but for days on end, since he will need at least thirty days to transport his troops under the most favorable conditions and at least six more to group and organize them on English soil. The fact that the limited accommodations of French ports will oblige the invaders to arrive in driblets will facilitate their destruction; and they will, of course, become both seasick and confused through their notorious incompetence at sea. And if by some chance they do secure a foothold, we will fall back in good order, forcing

$$
{ }_{1} 803,4 \text { to, } 39 \mathrm{pp} \text {. }
$$

${ }^{7}$ Pages 6-7. 
them to extend tenuous lines of communication, retaining strong points in their rear, harassing them by day and night.

With our third pamphlet, the emphasis swings back from Britain's invincibility to her grave peril. An Appeal from the Passions to the Sense of the Country, upon Buonaparté and Invasion is as nearly frenetic as the thoughts of an Englishman are likely to become in the face of danger. It nicely illustrates the hot intuitive muddle prevailing at the moment. At first the author is certain that invasion is imminent. Let us, accordingly, order our navy to blockade every French port, harbor, and creek and at the same time cruise up and down the Channel continuously; let us make our coasts impregnable-attain complete defence. But suddenly our mentor blows cold:

I think I behold this capricious, insolent, and infuriate Corsican, who has so long strutted about, acting the Roman, now, at this instant, stalking along upon the opposite beach, ... I I think I hear him saying, with a Satanic grin, "Where now, ye haughty islanders, is your boasted and distinctive pre-eminence from your insular situation? I shall, in spite of it, force you, like others upon the continent, from whom no accursed sea divides me, to become an armed nation; I shall thus deprive you of that complete confidence and security, which, enabling your lower ranks to attend, uninterrupted, to arts, agriculture, and manufactures, have brought them to a pitch unknown, and as yet unattainable by any other nation; and having thus rendered turbid the sources of that commerce, prosperity, and wealth, . . . I shall by degrees effect my purpose, and ye shall, in this way, become one day the certain, though perhaps the last victim of my ambition in Europe. What delight does it give my soul, ye proud but foolish Britons, to behold you thus running into the snare which I have set for you, baited with invasion!"

But this, too, may be a false lead, and again the writer reverses his course. Let us act immediately to turn our militiamen into regulars and train "the Mass of the People" in the use of arms-pikes, if necessary-, so that they may be mobilized into regiments stiffened with veteran riflemen and "Horse-Artillery."

One wonders what would have happened had the French suddenly appeared in force off the white cliffs. And note the antiquity of it-pikes! Other busybodies exhort every man to take up his own musket, or "a Pitch-fork, or a Hedge-stake if you cannot procure a Musket." In January 1804 a correspondent in The Gentleman's

8 London, 1803,4 to, $17 \mathrm{pp}$.

11 Klingberg and Hustvedt, op. cit., p. 7 .

9 Pages I I-I 2.

10 Pages I 5-16. 
Magazine observes: "I was reading the other day an account of more than a hundred thousand of our volunteers being supplied with pikes ..."; but a pitchfork will serve as well, and he recommends one to every householder, for "were a thief to break into your house at night, it might be of admirable use, as well as to give a foraging party of the French a proper reception."12

Among invasion writers were preachers. The fourth of our tracts is Obedience to Government, Reverence to the Constitution, and Resistance to Bonaparte, ${ }^{13}$ a sermon delivered by the Reverend Charles Edward Stewart at the Assizes held at Bury St. Edmund's in July 1803 . Its arch-Toryism is peppered with denunciation of Napoleon, "the reproach, the scourge, and execration of the World-THE vioLATOR OF TREATIES, THE PLUNDERER OF DEFENCELESS AND NEUTRAL NATIONS, THE OPPRESSOR OF HIS ALLIES, THE MURDERER OF HIS PRISONERS, THE POISONER OF HIS SICK, THE PROFESSOR AND DISBELIEVER OF ALL RELIGIONS; APOSTATE FROM HIS SAVIOUR; BLASPHEMER OF HIS God." ${ }^{4}$ Whereas to the caricaturists Napoleon, though a perverted little monster, is slightly comic, to the clergyman he is just a monster.

The last three pamphlets of our collection came out in $\mathrm{I} 804$, while the warning drum still beat. One of these is offered as the work of "an Englishman, late a captive in France" and the possessor of confidential information, and is graced with a long and pompous title, which reads in part: An Accurate Detail of Several Important Political Occurrences That Have Taken Place in France, Since the Peace of Amiens; with Appropriate Observations, Tending to Develop the Secret Designs of Bonaparte, against This Country. ${ }^{15}$ Although like the Reverend Mr. Stewart he belabors Napoleon with epithets like "the modern Attila"16 and "the dwarf Emperor of St. Cloud," concentrates his efforts on two precise admonitions: not to make peace with France while Napoleon remains in power, and to abandon the policy of financing useless and self-seeking allies. His isolationist propaganda is what we should call "realistic," busied exclusively with national self-regard. He presents a state of affairs on the Continent suggestive of that of r940: unspeakable treatment of foreigners by

${ }^{12}$ LXXiv, i, 6.

${ }^{14}$ Page I 5.
${ }^{13}$ Bury St. Edmund's, London, etc., 1803, 4to, 16 pp. 15 London, I 804, 8vo, 8 I pp.
${ }^{16}$ Page 9. 
the enemy, "contributions, exactions, forced-loans" levied upon defenceless states, enthusiasm for invasion reaching the point where the worst punishment in the enemy army was assignment to garrison duty inland. The writer, with his inside knowledge, predicts no fullscale attack but only "predatory expeditions"19 for which we might well retaliate with raids of our own. His main injunction, however, is to refuse to negotiate with the Emperor:

A peace with France during his usurpation could scarcely be considered as a truce that would last five years; for where can he now find a guarantee, whose recognizance could ensure his good behaviour for a month? What then could be expected from a peace with such a man, but a temporary respite from the calamities of war, which would return with increased violence, when he found himself in a condition to renew hostilities with any' likelihood of success? ${ }^{20}$

This Usurper, like the Dey of Algiers, must support himself by war.-You can place no reliance on his oaths, promises, or engagements. ${ }^{21}$

The same kind of "realistic" approach characterizes Thoughts on the National Defence. ${ }^{22}$ We should cease from subsidizing our ineffectual allies and thereby teach them to defend themselves. All nations can be depended upon to act exclusively for their own interests; our so-called allies can scarcely be said to be exerting themselves to lighten the pressure upon us. It is enough for us to contribute to the cause a naval war with France, meanwhile making ourselves secure and with the least possible interruption to our economic life, upon which the existence of our army and navy depends. This security we must achieve without resort to "violent projects" and pressing but rather by reducing our home guard (which is well enough for the gentry but pampering to the expendable populace), increasing the size of our militia and disciplining it in more up-todate maneuvers, and ameliorating conditions in the regular army. For what are we fighting, anyway? Simply to preserve the balance of power in Europe.

By far the best informed, most sensible, and most influential of our seven tracts (and the only one but Stewart's that is not anonymous) is An Enquiry into the Present State of the Military Force of the British Empire, with a View to Its Re-organization ${ }^{24}$ by Lieutenant-

\footnotetext{
${ }^{18}$ Page I4.

19 Page 26.

${ }^{22}$ London, I804, 8vo, $139 \mathrm{pp}$.

${ }^{23}$ Page 15.

${ }^{20}$ Pages 28-29. 21 Page 74.
} 
Colonel Robert Thomas Wilson, K.M.T., a gallant and intelligent soldier at the beginning of a brilliant career. He is plain-spoken but courteous and insists that positive security have precedence over wounded feelings. He sweetens his bitter dose with the flowery style of the day and an occasional Latin quotation.

A professional soldier, Sir Robert is quick to penetrate below the surface in military affairs. Our land forces number 500,000, but the majority are complete amateurs. Those who point to the successes of the peasant armies of the French Republic should note (r) that those raw levies were stiffened throughout with regular troops and (2) that at first they lost a great deal of territory, as much as would suffice to bring an invader to London itself. And touching our volunteers, it is a truism that an armed force is as good as its officers. Have theirs the experience and can they inspire the respect needed to hold their men steady? Can these well-intentioned gentlemen have acquired overnight the qualities of the professional officer? It is well known that rank in the home guard has been bestowed upon gentlemen quite innocent of military training; in fact, few gentlemen will condescend to accept a regimental commission below that of a field officer, a rank to which in the regular army only an officer of at least six years' standing can aspire. In the event of a crisis it is conceivable that one of these raw colonels might find himself in command of an army! It is a pity (Sir Robert insinuates) that such a large volunteer army was formed; when a whole nation marches, vital industries languish. Let us at least improve the organization, seek more experienced officers, standardize regulations, and abolish all this nonsense about elaborate equipment and uniforms. As the King himself remarked, "There is no hardship in such times to wear a shirt a week." ${ }^{25}$ Similarly, the militia and the guards are luxuries beyond our means, at least in their present numbers. So low is the morale of the former that we actually have to advertise for officers! Less futile is the army of reserves, since it encourages and facilitates the en-

${ }^{25}$ Page 2I, n. r. Jack Werner records that the home guard equipment included "one worsted or flannel night-cap to tie under the chin" (We Laughed at Boney; or, We've Been through It All Before [London: W. H. Allen and Co., 1943], p. Ior). Lending support to Sir Robert's indictment of the volunteers is a report of the time boasting that many of them are capable of hitting a target three feet in diameter at roo yards, at least every fifth or sixth shot (H. F. B. Wheeler and A. M. Broadley, Napoleon and the Invasion of England. The Story of the Great Terror [London: John Lane, The Bodley Head, 1908], 11, 64). 
trance of civilians into military life. All of these four branches of the land forces are well enough in less serious times; now they serve mainly to deprive the regular army of recruits.

Sir Robert is just as critical of the regular army, though admitting that it has virtually to be created anew with every war and so is obliged to enter the conflict under great disadvantages. We should form and maintain a force commensurate with England's rank among countries, and to that end certain reforms are sorely needed. We must make the military life more attractive and dignified by raising the pay of officers (scarcely changed from that of the days of Queen Anne) and by distributing distinctions less lavishly, and, more important, by modifying the customs of life enlistment, of frequent and brutal corporal punishment, and of dredging the depths of society for recruits.

This "textbook of British embarrassments" violent comment in the public press. An important document in humanitarian progress in military affairs, ${ }^{27}$ it has but one real blot: Sir Robert's claim for the English of the right to pillage, on the precedent of French example.

The national tumult recorded in these seven pamphlets of the Great Terror soon abated. England was spared invasion by the strain that a two-front war exerted upon Napoleon's resources. He sustained the threat as long as he could. In August, I 804, he held a grand fête at Boulogne, and a year later he reviewed there a line of soldiery nine miles long. But three weeks thereafter he abruptly turned the Grande Armée eastward. Trafalgar ended the menace. As Pitt declared in the shortest (possibly the best) speech ever delivered on an official occasion, "England has saved herself by her exertions, and will, I trust, save Europe by her example." Nevertheless, Napoleon left a large force to guard the iron coast and attempted in 1807 and once again in $18 \mathrm{I}$ I to revive his crippled invasion resources. England was not truly secure until after Waterloo.

When Mr. Winston Churchill made his magnificent address to his nation after Dunkirk, he and his audience well realized that this was not the first time that England had stood alone. And the writers also of these now disintegrating pamphlets had been fully aware that

${ }^{26}$ Cobbett's Spirit of the Public Journals, I (October 13, 1804), I 46 .

27 Dictionary of National Biography, art. "Sir Robert Thomas Wilson." 
the invasion of their island had been traditional in French policy long before Napoleon. Indeed, appeals to arms, defence associations, and volunteering for home guard duty are a legacy from the Great Terror of I 588; and the Elizabethan "musters" may be said to underlie the home guard movements of the eighteenth century, the Napoleonic period, and World War II alike. The Harleian Miscellany, published in the I 740 's, reprinted a number of tracts dating from I 588, I 593, I642, I692, I696, and I 70I which warn of impending invasion and offer counsel that would not have come amiss in 1803 - or 1940. And I have felt that to underscore the parallels between 1803 and 1940 revealed in our seven pamphlets would be an impertinence. Plus ça change, plus c'est la même chose. 